\title{
УДОСКОНАЛЕННЯ ЛІКУВАЛЬНО-ЕВАКУАЦІЙНИХ ЗАХОДІВ У ДЕСАНТНО-ШТУРМОВИХ ВІЙСЬКАХ ЗБРОЙНИХ СИЛ УКРАЇНИ В УМОВАХ ЗБРОЙНОГО КОНФЛІКТУ
}

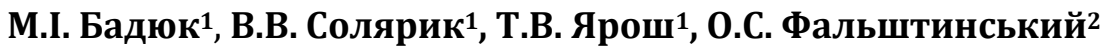

\author{
1Українська військово-медична академія, м. Київ, Україна \\ ${ }_{2}^{2}$ Командування Десантно-штурмових військ Збройних Сил України, м. Житомир, Україна
}

\begin{abstract}
Мета. Наукове обгрунтування удосконалення системи ЛЕЗ у ДШВ ЗС України через приведення організаційно-штатної структури медичних підрозділів частин ДШВ у відповідність до специбічних умов діяльності цього роду військ в умовах збройного конфлікту.

Методи дослідження. Проаналізований розподіл локалізації поранень у тактичних підрозділах СВ ЗС України в зоні проведення АТО/ООС протягом 2017-2018 рр. На підставі звітів та заповнених польових медичних карток (ПМК) Ф-300 (n=114), була зібрана та проаналізована інформація щодо локалізації поранень у військовослужбовців ДШВ ЗС України (79 і 95 Окремі десантно-штурмові бригади та 25 Окрема повітряно-десантна бригада) в зоні проведення АТО/OОС за той же період, а також у підрозділах ДШВ, що приймали участь у рейдових діях протягом 2014 р. Методологія дослідження базувалася на системному підході. Для вирішення поставлених завдань застосовувались наступні методи: системного аналізу (системно-історичний, системно-структурний, системно-комунікативний) та методи статистичного аналізу. При обробці результатів досліджень використовувалися методика $\varphi$ - Фішера, критерії $\chi^{2}-$ Пірсона і $t$ - Стьюдента.
\end{abstract}

Результати. При порівняльному аналізі розподілу локалізації поранень під час проведення рейдових дій підрозділами ДШВ, з'ясувалось, що він відрізняється від такого розподілу у тактичних підрозділах СВ $i$ ДШВ в зоні проведення АТО/OOC із статистично значущим ( $p \alpha(t, d f) \leq 0,05)$ переважанням поранень голови i кінцівок, причому шанс отримати поранення голови (при розрахунку відношення шансів) у цього контингенту за таких умов збільшується у 1,3 рази, що викликано принципово іншою бойовою обстановкою, способами і методами ведення бойових дій. Це акцентує увагу на необхідності наявності хірургічної та анестезіологічної компоненти при наданні медичної допомоги в підрозділах і частинах ДШВ при виконанні спещифічних завдань в умовах ізоляції та автономного функціонування.

Висновки. Необхідною умовою для успішного виконання завдань, притаманних ДШВ ЗС України (десантно-рейдові, десантно-ударні, десантно-штурмові дії, дії в умовах десантування) є удосконалення системи ЛЕЗ шляхом приведення організаційно-штатної структури медичних підрозділів частин цього роду військ у відповідність до специфічних умов діяльності, шляхом підсилення їх лікарями-спеціалістами, які можуть повноцінно надавати первинну та елементи вторинної медичної допомоги. Ця ідея в ході виконання роботи була реалізована в практичну площину, шляхом розробки і затвердження відповідної Директиви ГШ ЗС України (2018р.), з введенням в штати медичних рот частин ДШВ лікарів-хірургів $i$ лікарів-анестезіологів, що є особливо актуальним в умовах ізоляції та автономного функціонування підрозділів ДШВ при виконанні специфічних бойових завдань.

Ключові слова. Лікувально-евакуаційні заходи, медична рота, польова медична картка Ф-З00, специфічні умови діяльності ДШВ, організаційно-штатна структура, вузькі спеціалісти (хірурги та анестезіологи).

Вступ. Десантно-штурмові війська (ДШВ) Збройних Сил (3С) України - це окремий рід військ, що спроможний виконувати завдання за умов високої маневреності та автономності дій i призначений для виконання бойових завдань, що неможливо виконати за допомогою інших сил та засобів збройної боротьби $[4,6,9]$. Високий ступінь бойової готовності військових підрозділів і частин ДШВ 3 С України значною мірою залежить від їх медичного забезпечення [8]. Науковий аналіз світових і вітчизняних джерел інформації щодо поглядів на систему ЛЕЗ у десантних військах збройних сил різних країни світу засвідчив, що умови діяльності медичної служби десантних військ визначаються перш за все діями в ізоляції та у відриві від основних сил, потребою в підсиленні силами та засобами зі збереженням необхідної автономності, ускладненням або неможливістю евакуації поранених і хворих, максимальним розширенням обсягу медичної допомоги при виконанні специфічних завдань, притаманних тільки цьому роду військ (десантно-штурмові, десантно-ударні, десантно-рейдові, десантно-пошукові та парашутно-десантні дії) [1,5,7,8].

\section{Мета дослідження - наукове} обгрунтування удосконалення лікувально- 
евакуаційних заходів (ЛЕЗ) у ДШВ ЗС України через приведення організаційно-штатної структури медичних підрозділів частин ДШВ у відповідність до специфічних умов діяльності цього роду військ в умовах збройного конфлікту.

Матеріали та методи дослідження. На першому етапі дослідження нами проаналізований розподіл локалізації поранень у тактичних підрозділах Сухопутних військ (СВ) 3С України в зоні проведення АТО/ООС протягом 2017-2018 рр. Далі, на підставі звітів та заповнених польових медичних карток (ПМК) Ф-300 (n=114), була зібрана та проаналізована інформація щодо локалізації поранень у військовослужбовців
ДШВ (79 і 95 Окремі десантно-штурмові бригади та 25 Окрема повітряно-десантна бригада) в зоні проведення АТО/OОС за той же період, а також у підрозділах ДШВ, що приймали участь у рейдових діях протягом 2014 р. Результати досліджень зведені у табл. 1. Методологія дослідження базувалася на системному підході. Для вирішення поставлених завдань застосовувались наступні методи: системного аналізу (системно-історичний, системно-структурний, системно-комунікативний) та методи статистичного аналізу. При обробці результатів досліджень використовувалися методика $\varphi$ - Фішера, критерії $\chi^{2}$ - Пірсона i t Стьюдента $[2,3]$.

Таблиия 1

Розподіл локалізації поранень у порівнюваних контингентах (абсолютні частоти)

\begin{tabular}{|l|c|c|c|}
\hline $\begin{array}{c}\text { Локалізація } \\
\text { поранення }\end{array}$ & $\begin{array}{c}\text { тактичні } \\
\text { підрозділи СВ у } \\
\text { АТО/ООС } \\
2017-2018 \text { pp. }\end{array}$ & $\begin{array}{c}\text { тактичні } \\
\text { підрозділи ДШВ у } \\
\text { АТО/ООС } \\
2017-2018 \text { pp. }\end{array}$ & $\begin{array}{c}\text { підрозділи ДшВ } \\
\text { у рейдових діях } \\
2014 \text { p. }\end{array}$ \\
\hline Голова & 390 & 37 & 290 \\
\hline Кінцівки & 560 & 50 & 370 \\
\hline Грудна клітка & 130 & 12 & 27 \\
\hline Черевна порожнина & 86 & 3 & 33 \\
\hline Поєднані & 252 & 22 & 155 \\
\hline Всього: & 1418 & 124 & 875 \\
\hline
\end{tabular}

Результати дослідження та їх обговорення. При порівнянні розподілів локалізації поранень у трьох досліджуваних контингентах військовослужбовців виявлено, що, в цілому, вони не розрізняються $\left(p_{\alpha}\left(\chi^{2}, d f=8\right)=0,55\right)$. В той же час, попарне порівняння локалізації поранень показали дещо іншу картину (табл. 2). Подібність розподілів локалізації поранень виявлена у тактичних підрозділах ДШВ та СВ, що пояснюється веденням одного виду бойових дій в районі проведення АТО/ООС протягом 2017-2018 рр. обома об’єктами порівняння.

При більш глибокому аналізі структури локалізації поранень у військовослужбовців (рис.1,2,3) встановлено, що в трьох досліджуваних контингентах статистично значущим $\left(p_{\alpha}(t, d f) \leq 0,05\right)$ було переважання частки при пораненнях кінцівок, яка склала $(39,5 \pm 2,6) \%$ - у тактичних підрозділах CB, $(40,3 \pm 8,7) \%$ - у тактичних підрозділах ДШВ. 3 трьох груп порівняння збільшення частки цих поранень спостерігалось у підрозділах ДШВ під час рейдових дій $(42,3 \pm 3,3) \%$. На другому місті за частотою йшли поранення голови, які склали майже однакову частку у тактичних підрозділах СВ та ДШВ: $(27,5 \pm 2,3) \%$ та $(29,8 \pm 8,3) \%$ відповідно. Дещо більшою частка поранень голови спостерігалась у підрозділах ДШВ під час рейдових дій $(33,1 \pm 3,1) \%$. Поранення грудної клітки склали майже однакову частку в тактичних підрозділах СВ та ДшВ: $(9,2 \pm 1,5) \%$ та $(9,7 \pm 5,3) \%$ відповідно.

У підрозділах ДШВ під час рейдових дій ця частка була меншою: $(3,1 \pm 1,2) \%$. Найбільша частка поранень черевної порожнини спостерігалась у підрозділах CB: $(6,1 \pm 1,2) \%$. У тактичних підрозділах ДШВ у зоні АТО/ООС та в умовах рейдових вона була майже однаковою: $24,2 \% \quad[2,0 ; 4,2] \%$ та $(3,8 \pm 1,3) \%$ відповідно. Частка поєднаних поранень була майже однакова в усіх досліджуваних контингентах: $\quad(17,8 \pm 2,0) \%, \quad(17,7 \pm 6,8) \%$, $(17,7 \pm 2,5) \%$ відповідно. Наведені результати підтверджують порівняння за критерієм $\chi^{2}-$ Пірсона (табл. 2). 
Таблиця 2

Рівні статистичної значущості $p_{\alpha}\left(\chi^{2}, d f=4\right)$ при попарному порівнянні досліджуваних контингентів

\begin{tabular}{|c|c|c|c|}
\hline Контингенти & $\begin{array}{c}\text { тактичні } \\
\text { підрозділи СВ у } \\
\text { АТО/О0С } \\
\text { 2017-2018 pp. }\end{array}$ & $\begin{array}{c}\text { тактичні } \\
\text { підрозділи ДшВ } \\
\text { у АТО/О0С } \\
\text { 2017-2018 рр. }\end{array}$ & $\begin{array}{c}\text { підрозділи ДШВ } \\
\text { у рейдових діях } \\
2014 \text { р. }\end{array}$ \\
\hline $\begin{array}{l}\text { тактичні підрозділи СВ у } \\
\text { АТО/ООС 2017-2018 рр. }\end{array}$ & 1 & 0,55 & 0,00001 \\
\hline $\begin{array}{l}\text { тактичні підрозділи ДШВ } \\
\text { у АТО/ООС 2017-2018 pp. }\end{array}$ & 0,55 & 1 & 0,01 \\
\hline $\begin{array}{c}\text { підрозділи ДШВ у } \\
\text { рейдових діях } 2014 \text { р }\end{array}$ & 0,00001 & 0,01 & 1 \\
\hline
\end{tabular}

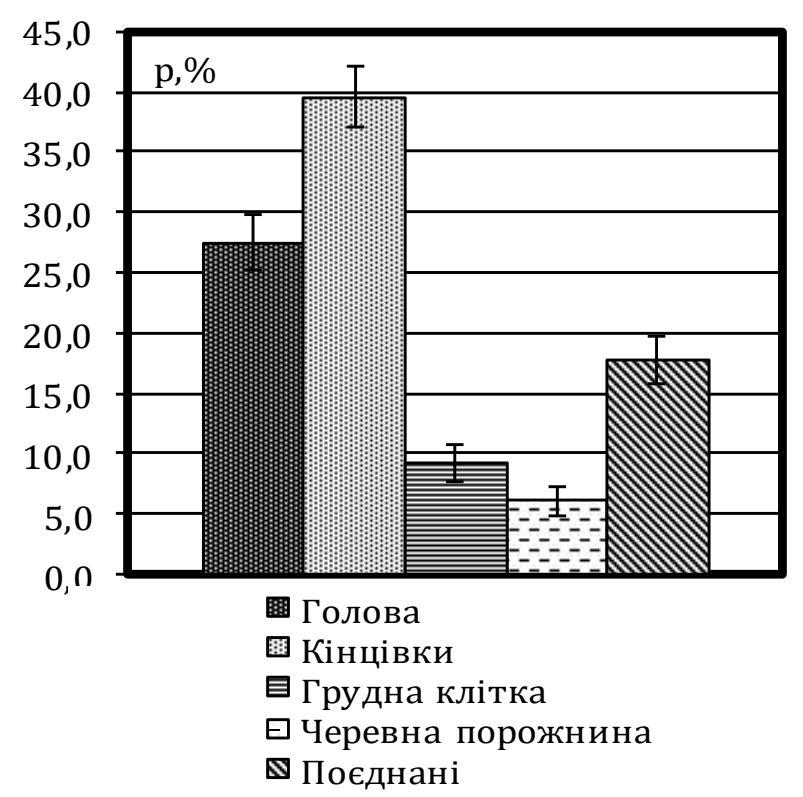

Рисунок 1. Структура локалізації поранень у тактичних підрозділах СВ в зоні проведення АТО/ООС протягом 2017-2018 pр.

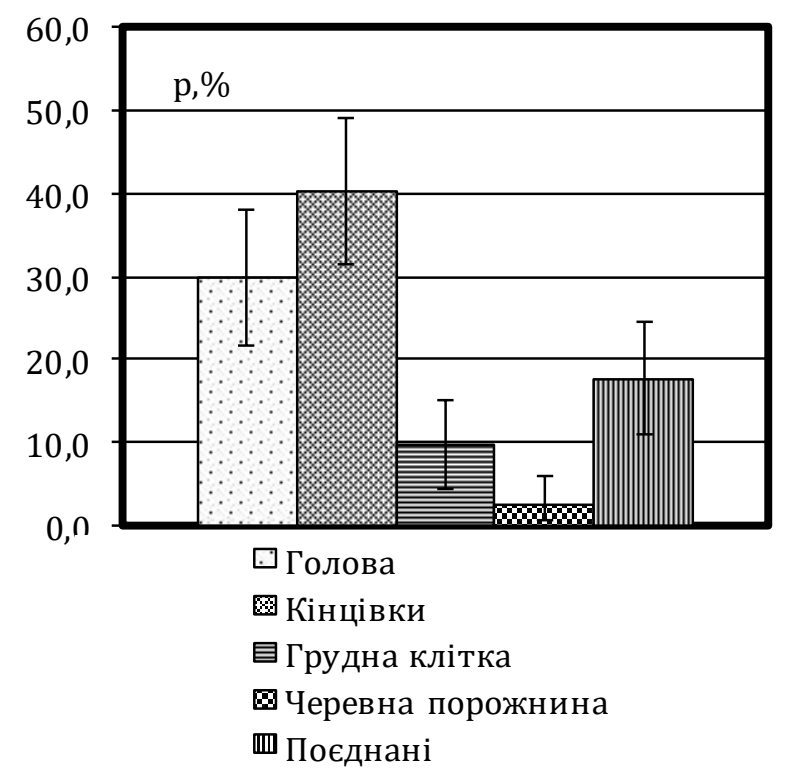

Рисунок 2. Структура локалізації поранень у підрозділах ДШВ в районі проведення АТО/ООС протягом 2017-2018 рр.
Оскільки розподіли локалізації поранень у тактичних підрозділах СВ та ДШВ в досліджуваний період не розрізнялись, тому для визначення особливостей структури поранень у підрозділах ДШВ під час рейдових дій в якості контролю були обрані тактичні підрозділи СВ в зоні проведення АТО/OОС. Статистично значуща різниця $\left(p_{\alpha}(t, d f) \leq 0,05\right)$ у частках поранень порівнюваних контингентів була виявлена при пораненнях голови (рис. 4), грудної клітки (рис. 5) та черевної порожнини (рис. 6).

Для визначення збільшення/зменшення шансів отримати поранення голови, грудної клітки та черевної порожнини військовослужбовцями підрозділів ДШВ під час виконання рейдових дій у порівнянні із тактичними підрозділами СВ нами було розраховано відношення шансів (ВШ) отримати наведені поранення у двох контингентах [2].

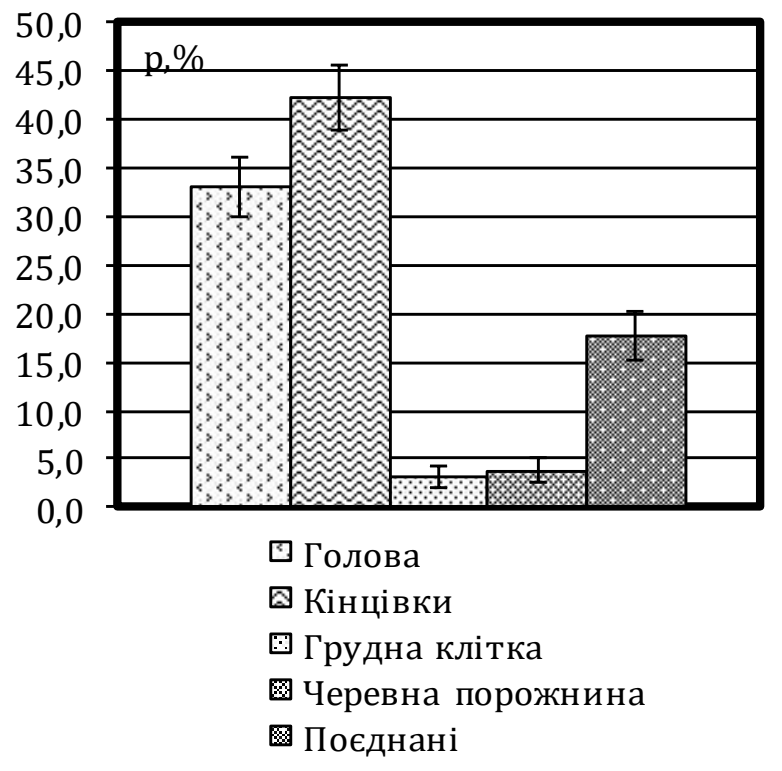

Рисунок 3. Структура локалізації поранень у підрозділах ДШВ, які приймали участь у рейдових діях (2014р.). 


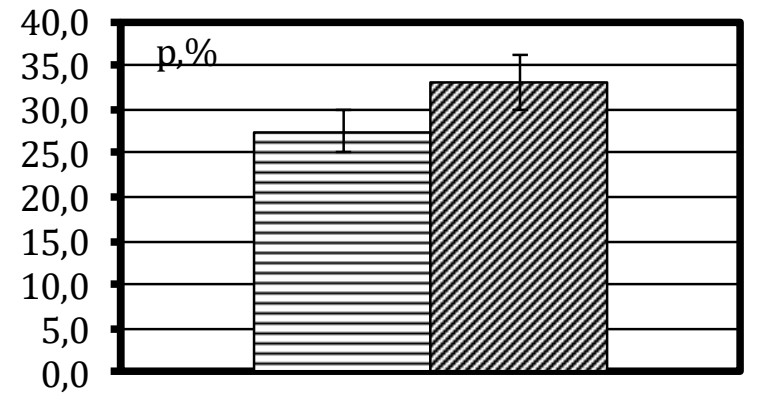

曰 Тактичні підрозділи СВ у АТО/OOC

Підрозділи ДШВ у рейді у 2014 р.

Рисунок 4. Частки поранень голови у загальній структурі локалізації поранень у підрозділах ДШВ, що приймали участь у рейдових діях, та у тактичних підрозділах СВ в районі проведення АТО/ООС.

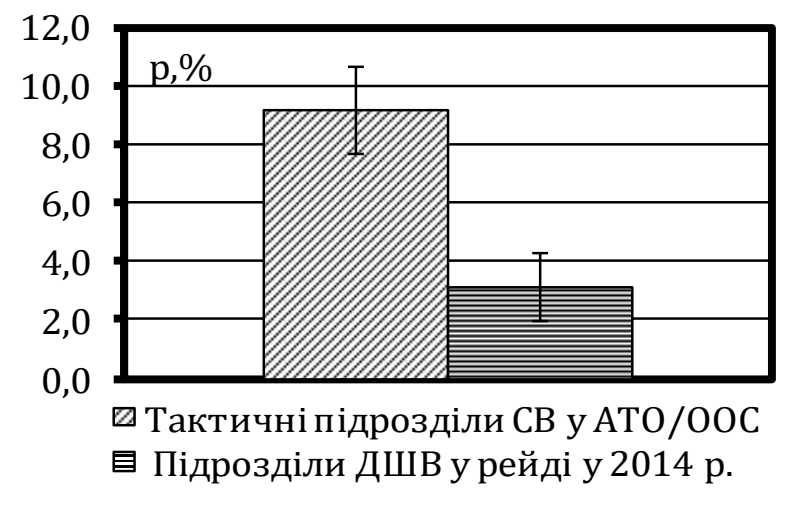

Рисунок 5. Частки поранень грудної клітки у загальній структурі локалізації поранень у підрозділах ДШВ, що приймали участь у рейдових діях, та у тактичних підрозділах СВ в районі проведення АТО/ООС.

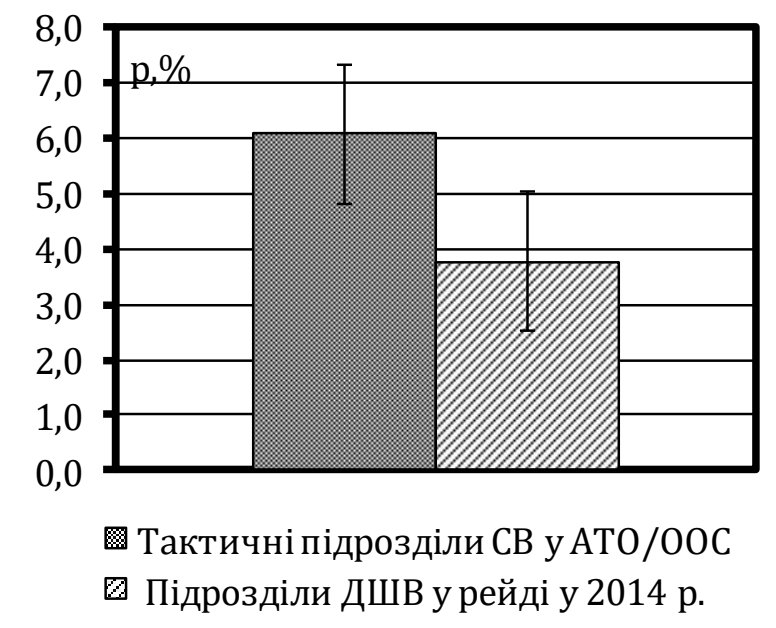

Рисунок 6. Частки поранень черевної порожнини у загальній структурі локалізації поранень у підрозділах ДШВ, що приймали участь у рейдових діях, та у тактичних підрозділах СВ в районі проведення АТО/ООС.
Статистично значущим $\left(p_{\alpha}(t, d f) \leq 0,05\right)$ виявилося тільки ВШ для поранень голови: ВШ=1,3, ДІ(ВШ)=[1,1; 4,4] (довірчий інтервал не включає 1). Тобто незначне, на перший погляд, збільшення частки поранень голови у військовослужбовців підрозділів ДШВ під час рейдових дій у порівнянні із тактичними підрозділами СВ в зоні проведення АТО/ООС призвело до збільшення шансу отримати ними за цих умов поранення голови у 1,3 рази.

ВШ поранень грудної клітки та черевної порожнини порівнюваних контингентів не було статистично значущим, тобто зменшення частки перелічених поранень не призведе до зменшення шансу отримати ці поранення військовослужбовцями ДШВ під час рейдових дій порівняно із тактичними підрозділами СВ в зоні проведення АТО/ООС. В подальшому, при аналізі роботи медичної служби підрозділів ДШВ під час ведення бойових дій в районі АТО/ООС протягом 2017-2018 рр. було визначено середній час надання допомоги на полі бою, час евакуації поранених з поля бою до МПБ та з МПБ до ВМГ і міських лікарень прифронтових населених пунктів. Це дозволило нам встановити середній термін надання домедичної, первинної та вторинної медичної допомоги.

Порівнявши вищевказані терміни 3 еталонними значеннями 3 використанням методу розрахунку напівширини довірчого інтервалу за допомогою критеріального числа Стьюдента ми отримали результат, який свідчить про те, що різниця у термінах надання медичної допомоги на зазначених етапах не була статистично значущою.

\section{Висновки}

1. Науковий аналіз світових і вітчизняних джерел інформації щодо поглядів на систему ЛЕЗ у десантних військах збройних сил різних країни світу дозволив обгрунтувати потребу в іiі удосконаленні для військових частин ДШВ 3С України в умовах збройного конфлікту.

2. Порівняльний аналіз розподілу локалізації поранень при проведенні рейдових дій підрозділами ДШВ відрізняється від такого розподілу у тактичних підрозділах СВ і ДШВ в зоні проведення АТО/OOC із статистично значущим $\left(p_{\alpha} \quad(t, d f) \leq 0,05\right)$ переважанням поранень голови і кінцівок, причому шанс отримати поранення голови (при розрахунку ВШ) у цього контингенту за таких умов збільшується у 1,3 рази, що викликано принципово іншою бойовою обстановкою, способами і методами ведення бойових дій. Це 
акцентує увагу на необхідності наявності хірургічної та анестезіологічної компоненти при наданні медичної допомоги в підрозділах і частинах ДШВ при виконанні специфічних завдань в умовах ізоляції та автономного функціонування.

3. Зважаючи на досвід медичного забезпечення частин і підрозділів ДШВ ЗС України при виконанні рейдових дій в умовах збройного конфлікту, 3 урахуванням результатів наших досліджень, можна 3 впевненістю стверджувати, що необхідною умовою для успішного виконання завдань, притаманних саме цьому роду військ (десантно-рейдові, десантно-ударні, десантноштурмові дії, дії в умовах десантування) $\epsilon$ удосконалення системи ЛЕЗ шляхом

\section{Література}

1. Бадюк M.I. Особливість своєчасності надання медичної допомоги на етапах медичної евакуації у провідних країнах світу (огляд літератури) / M.I. Бадюк, Д.В. Ковида // Проблеми військової охорони здоров'я. - 2012. - Випуск 31. - С. 20 - 25.

2. Бадюк M.I. Основні шляхи досліджень у військовій медицині: Навч. посібник / Бадюк М.I., Ярош Т.В. -К.: УВМА, 2011. -292 с.

3. Бадюк M.I., Ярош Т.В. Методичні рекомендації до виконання індивідуальних завдань / Бадюк M.I., Ярош Т.В. та ін. -К.: “Видавництво Людмила”, 2019. $92 \mathrm{c}$.

4. Бараш Ю.Н. Трансформація організаційної структури Збройних Сил України на сучасному етапі / Ю.Н. Бараш // Стратегічні пріоритети,. - 2007. -№ 4(5). -C. 6-13.

5. Верба А. В. Стан та проблемні питання медичного забезпечення в зоні проведення антитерористичної операції в різні періоди / А. В. Верба // Медичне забезпечення антитерористичної операції: науково-організаційні та медико-соціальні

\section{References}

1. Badiuk, M.I., Kovida, D.V. (2012). Peculiarity of timeliness of medical care at the stages of medical evacuation in the leading countries of the world (literature review). Military health problems. Issue 31. 20 -25 .

2. Badiuk, M.I, Yarosh, T.V. (2011). The main ways of research in military medicine: Textbook. K.: UVMA, 292 p.

3. Badiuk, M.I., Yarosh, T.V. etc. (2019). Methodical recommendations for individual tasks. $\mathrm{K}$ :: Lyudmila Publishing House, $92 \mathrm{p}$.

4. Barash, Yu. N. (2007). Transformation of the organizational structure of the Armed Forces of Ukraine at the present stage. Strategic priorities. 4 (5). 6-13.

5. Verba, A. V. (2016). The state and problematic issues of medical care in the area of the anti-terrorist operation in different periods. Medical support of the anti-terrorist operation: scientific-organizational and medical-social aspects: Coll. Science. pr. SI « Marzeeva Institute of Public Health of the National Academy of Medical Sciences of Ukraine». K .: SE «NVC Priorities», 15-27. приведення організаційно-штатної структури медичних підрозділів частин ДШВ у відповідність до специфічних умов діяльності, підсиливши їх лікарями-спеціалістами, які можуть повноцінно надавати первинну та елементи вторинної медичної допомоги.

4. Ця ідея в ході виконання роботи була реалізована в практичну площину, шляхом розробки і затвердження відповідної Директиви ГШ ЗС України (2018р.), 3 введенням в штати медичних рот частин ДШВ лікарів-хірургів і лікарів-анестезіологів, що $\epsilon$ особливо актуальним в умовах ізоляції та автономного функціонування підрозділів ДШВ при виконанні специфічних бойових завдань.

аспекти: Зб. наук. пр. ДУ «Інститут громадського здоров'я ім. О.М. Марзєєва Національної академії медичних наук України». - К.: ДП «НВЦ Пріоритети», 2016. - № 45. - С. 15-27.

6. Гончарук М.Г. Зміст збройної боротьби за досвідом антитерористичної операції на півдні і на сході України. / Лекція. -К., Вид. НУОУ, 2014. -18 с.

7. Івчук В.М. Лікувально-евакуаційне забезпечення Високомобільних десантних військ Збройних Сил України в ході антитерористичної операції / Наук. робота на здобуття осв.-кваліфікац. рівня магістра військового управління. -К., 2016. -87 c.

8. Особливості медичного забезпечення Високомобільних десантних військ Збройних Сил України: навч. посібн. / Бадюк M.І., Солярик В.В., Козачок В.Ю., Середа І.К., Ковида Д.В., Тіщевський С.А., Івчук В.М. - К.: СПД Чалчинська Н.В., 2017. - 84 с.

9. Телелим В.М. Найважливіші аспекти розвитку збройної боротьби / Військо України. - 2012. - №1-2 (138) - C. 12-17.

6. Goncharuk, M.G. (2014). Contents of the armed struggle based on the experience of the anti-terrorist operation in the south and east of Ukraine. Lecture. - K., Ed. NUDU, $18 \mathrm{p}$.

7. Ivchuk, V.M. (2016). Medical and evacuation support of the Highly Mobile Airborne Troops of the Armed Forces of Ukraine during the anti-terrorist operation. Science. Work to obtain educational qualifications master's degree in military management. K., $87 \mathrm{p}$.

8. Badiuk, M.I., Solyaryk, V.V., Kozachok, V.Y., Sereda, I.K., Kovida, D.V., Tishchevsky, S.A., Ivchuk, V.M. (2017). Peculiarities of medical support of Highly Mobile Airborne Troops of the Armed Forces of Ukraine: textbook manual. $\mathrm{K}$.: SPD Chalchinskaya NV, $84 \mathrm{p}$.

9. Telelim, V.M. (2012). The most important aspects of the development of armed struggle. The Army of Ukraine. 1-2 (138). 12-17. 


\title{
УСОВЕРШЕНСТВОВАНИЕ ЛЕЧЕБНО-ЭВАКУАЦИОННЫХ МЕРОПРИЯТИЙ В ДЕСАНТНО- ШТУРМОВЫХ ВОЙСКАХ ВООРУЖЕННЫХ СИЛ УКРАИНЫ В УСЛОВИЯХ ВООРУЖЕННОГО КОНФЛИКТА
}

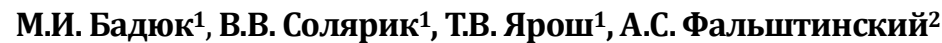

\author{
1Украинская военно-медицинская академия, г. Киев, Украина \\ ${ }^{2}$ Командование Десантно-штурмовых войск Вооруженных Сил Украины, г. Житомир, Украина
}

\begin{abstract}
Цель. Научное обоснование совершенствования системы ЛЭМ в ВС Украины путем приведения организационно-штатной структуры медицинских подразделений частей ДШВ в соответствие со специфическими условиями деятельности данного рода войск в вооруженном конфликте.

Методы исследования. Проанализировано распределение локализации ранений в тактических подразделениях СВ ВС Украины в зоне АТО/ООС в течение 2017-2018 г2. На основании отчетов и заполненных полевых медищинских карт (ПМК) Ф-300 (n=114) собрана и проанализирована информация о локализации ранений у военнослужащих ДШВ ВС Украины (79 и 95 Отдельные десантно-штурмовые бригады и 25 Отдельная воздушнодесантная бригада) в зоне АТО/ООС в тот же период, а также в подразделениях ДШВ, участвовавших в рейдовых действиях в 2014 2. Методология исследований основана на системном подходе. Для решения поставленных задач применялись следующие методы: системного анализа (системно-исторический, системно-структурный, системно-коммуникативный) и методы статистического анализа. При обработке результатов исследования использовалась методика $\varphi$ - Фішера, критерии $\chi^{2}$ - Пирсона и $t$-Стьюдента.

Результаты. При сравнительном анализе распределения локализации ранений при проведении рейдовых действий подразделений ДШВ было обнаружено, что оно отличается от такого распределения в тактических подразделениях СВ и ДШВ в зоне АТО/OОС со статистически значимым $(p \alpha(t, d f) \leq 0,05)$ преобладанием ранений головы и конечностей, причем шанс получить травму головы (при расчете отношения шансов) в этом контингенте в таких условиях увеличиваются в 1,3 раза, что вызвано принципиально иной боевой обстановкой, способами и методами ведения боевых действий. Это акцентирует внимание на необходимости наличия хирургического и анестезиологического компонентов при оказании медицинской помощи в подразделениях и частях ДШВ при выполнении специфических задач в условиях изоляции и автономного функционирования.
\end{abstract}

Выводы. Необходимым условием для успешного выполнения задач, присущих ДШВ ВС Украины (десантнорейдовые, десантно-ударные, десантно-штурмовые действия, действия в условиях десантирования) является усовершенствование системы ЛЭМ путем приведения организационно-штатной структуры медицинских подразделений этого рода войск в соответствие со специфическими условиями деятельности, путем усиления их врачами-специалистами, которые могут полноценно оказывать первичную и элементы вторичной медицинской помощи. Эта идея в ходе выполнения работы была реализована в практической плоскости путем разработки и утверждения соответствующей Директивы ГШ ВС Украины (2018), с введением в штаты медицинских рот частей ДШВ врачей-хирургов и врачей-анестезиологов, что особенно актуально в условиях изоляции и автономного функционирования подразделений ДШВ при выполнении специфических боевых задач.

ключевые слова: лечебно-эвакуационные мероприятия, медицинская рота, полевая медицинская карта Ф300, специфические условия деятельности ДШВ, организационно-штатная структура, узкие специалисты (хирурги и анестезиологи).

\section{IMPROVEMENT OF TREATMENT-EVACUATION MEASURES IN THE AIRBORNE TROOPS OF THE ARMED FORCES OF UKRAINE AT ARMED CONFLICT CONDITIONS}

\author{
M. I. Badiuk' ${ }^{1}$ V. V. Solyaryk' ${ }^{1}$ T.V. Yarosh'1, O. S. Falshtinsky² \\ ${ }^{1}$ Ukrainian Military Medical Academy, Kyiv, Ukraine \\ ${ }^{2}$ Airborne Command of the Armed Forces of Ukraine, Zhytomyr, Ukraine
}

The purpose. Scientific substantiation of improvement of the system of LES in the armed forces of Ukraine by bringing the organizational-personnel structure of medical units of the DSHV into conformity to the specific conditions of this kind of troops ' activity in the conditions of armed conflict.

Methods. The breakdown of localization of wounds in tactical units of the JI armed forces of Ukraine in the ATO/JFO zone during the years 2017-2018 was analyzed. On the basis of the reports and filled field medical cards (PMK) F-300 ( $n=114)$, information was collected and analysed for localization of wounded in the armed forces of Ukraine (79 and 95 separate Assault Brigade and 25 separate airborne assault Brigades). Brigade) in the ATO/JFO area during the same period, as well as in the DSHV units that took part in the raids during 2014, the research methodology was based on the system approach. The following methods were applied to solve the problems: system analysis (systematic-historical, systematic-structural, systematiccommunicative) and methods of statistical analysis. In processing the results of the research used the $\varphi$ technique - Fisher, the criteria $\chi^{2}$ - Pierson and $t$-Student.

Results. At the comparative analysis of distribution of wounds localization in carrying out the divisions of the DSHV, it was discovered that it differs from such distribution at tactical divisions of CB and DSHV in the ATO/JFO area with statistically 
meaningful $(p \alpha(t, d f) \leq 0,05)$. A predominance of wounds of the head and extremities, and the chance to get injured by the head (with the calculation of odds ratio) in this contingent under such conditions increases by 1.3 times, which is caused by a fundamentally different combat situation, methods and methods of conducting Hostilities. This focuses on the need for surgical and anesthetic components in the provision of medical care in units and parts of the DSHV in the performance of specific tasks in isolation and autonomous functioning.

Conclusion. The necessary condition for the successful fulfillment of the tasks inherent in THE armed forces of Ukraine (landing-raid, landing-drums, assault-assault operations, assault-landing actions) is improvement of the LES system by means of bringing the organizational-personnel structure of medical Subdivisions of this kind of troops in accordance with the specific conditions of activity, by strengthening by their doctors-specialists who can fully provide primary and elements of secondary medical care. This idea during the performance of the work was implemented in the practical plane by developing and approving the relevant directive of the armed Forces of Ukraine (2018), with the introduction of the medical mouth parts of the DSHV surgeons, physicians and anesthesiologists, who are particularly relevant in Conditions of isolation and autonomous functioning of DSHV units in the performance of specific combat tasks.

Key words. Medical-evacuation measures, medicine, field Medical card F-300, specific conditions of the DSHV activity, organizational-staff structure, narrow specialists (surgeons and anesthesiologists).

Конфлікт інтересів: відсутній.

Conflicts of interest: authors have no conflict of interest to daclare.

Відомості про авторів:

Бадюк M.I., A,B,C,D,E,F доктор медичних наук, професор, начальник кафедри організації медичного забезпечення збройних сил Української військово-медичної академії, м. Київ, Україна.

Солярик B.B., C,D,E, кандидат медичних наук, доцент, професор кафедри організації медичного забезпечення збройних сил Української військово-медичної академії, м. Київ, Україна.

Ярош Т.В., С,Е, кандидат технічних наук, доцент, доцент кафедри організації медичного забезпечення збройних сил Української військово-медичної академії, м. Київ, Україна.

Фальштинський О.C., C,D,E майор медичної служби, начальник військово-медичної служби Командування Десантно-штурмових військ Збройних Сил України, м. Житомир, Україна.

$A$ - концепція та дизайн дослідження; $B$ - збір даних; $C$ - аналіз та інтерпретація даних;

$D$ - написання статmi; $E$ - редагування статmі; F- остаточне затвердження статті.

\section{Сведения об авторах:}

Бадюк М.И., доктор медицинских наук, профессор, начальник кафедры организации медицинского обеспечения вооруженных сил Украинской военно-медицинской академии, г. Киев, Украина

Солярик В.В.,кандидат медицинских наук, доцент, профессор кафедры организации медицинского обеспечения вооруженных сил Украинской военно-медицинской академии, г. Киев, Украина

Ярош Т.В., кандидат технических наук, доцент, доцент кафедры организации медицинского обеспечения вооруженных сил Украинской военно-медицинской академии, г. Киев, Украина.

Фальштинский А.С., майор медицинской службы, начальник военно-медицинской службы Командование десантно-штурмовых войск Вооруженных Сил Украины, г. Житомир, Украина.

Information about authors:

Badiuk M.I., A,B,C,D,E,F MD, professor, Head of department of Armed Forces Medical Organization of Ukrainian Military Medical Academy, Address: 45/1 Moscow str., building 33, 01015, Kyiv, Ukraine,

E-mail: badiuk@ukr.net, https://orcid.org/0000-0002-2995-0910

Solarik V.V., ,C,D,E, PhD (Med), Associate Professor, professor of department of Armed Forces Medical Organization of Ukrainian Military Medical Academy, E-mail: solyarikw@gmail.com,

Yarosh T.V., , E, candidate of Technical Sciences, Associate Professor, Associate Professor of the Department of Medical Support of the Armed Forces of the Ukrainian Military Medical Academy, Kyiv, Ukraine.

Falshtynsky 0.S., C,D,E Major MS, Chief of the Military Medical Service of the Airborne Command of the Armed Forces of Ukraine, Zhytomyr, Ukraine.

$A$ - research concept and design; $B$ - collection and/or assembly of data; $C$ - data analysis and interpretation;

$D$ - writing the article; $E$ - critical revision of the article; $F$ - final approval of the article.

Адреса для листування: вул. Московська, 45/1, буд. 33, м. Київ 01015 